\title{
Annotating BCMA Expression in Multiple Myelomas
}

Weijun Wei ${ }^{1, *}, \#$, You Zhang ${ }^{1, \#}$, Di Zhang ${ }^{1}$, Qiufang Liu' ${ }^{2}$, Shuxian An ${ }^{1}$, Yumei Chen ${ }^{1}$, Gang Huang ${ }^{1,3}$, Jianjun Liu ${ }^{1, *}$

${ }^{1}$ Department of Nuclear Medicine, Institute of Clinical Nuclear Medicine, Renji Hospital, School of Medicine, Shanghai Jiao Tong University, Shanghai 200127, China

${ }^{2}$ Department of Nuclear Medicine, Fudan University Shanghai Cancer Center, Fudan University, Shanghai 200032, China

${ }^{3}$ Shanghai Key Laboratory of Molecular Imaging, Shanghai University of Medicine and Health Sciences, Shanghai 201318, China

* Corresponding Authors: Weijun Wei, Department of Nuclear Medicine, Renji Hospital, School of Medicine, Shanghai Jiao Tong University, Shanghai 200127, China; e-mail: wwei@shsmu.edn.cn. Jianjun Liu, Department of Nuclear Medicine, Renji Hospital, School of Medicine, Shanghai Jiao Tong University, Shanghai 200127, China; e-mail: nuclearj@163.com.

\# The authors contributed equally to the work. 


\section{Supplemental materials:}

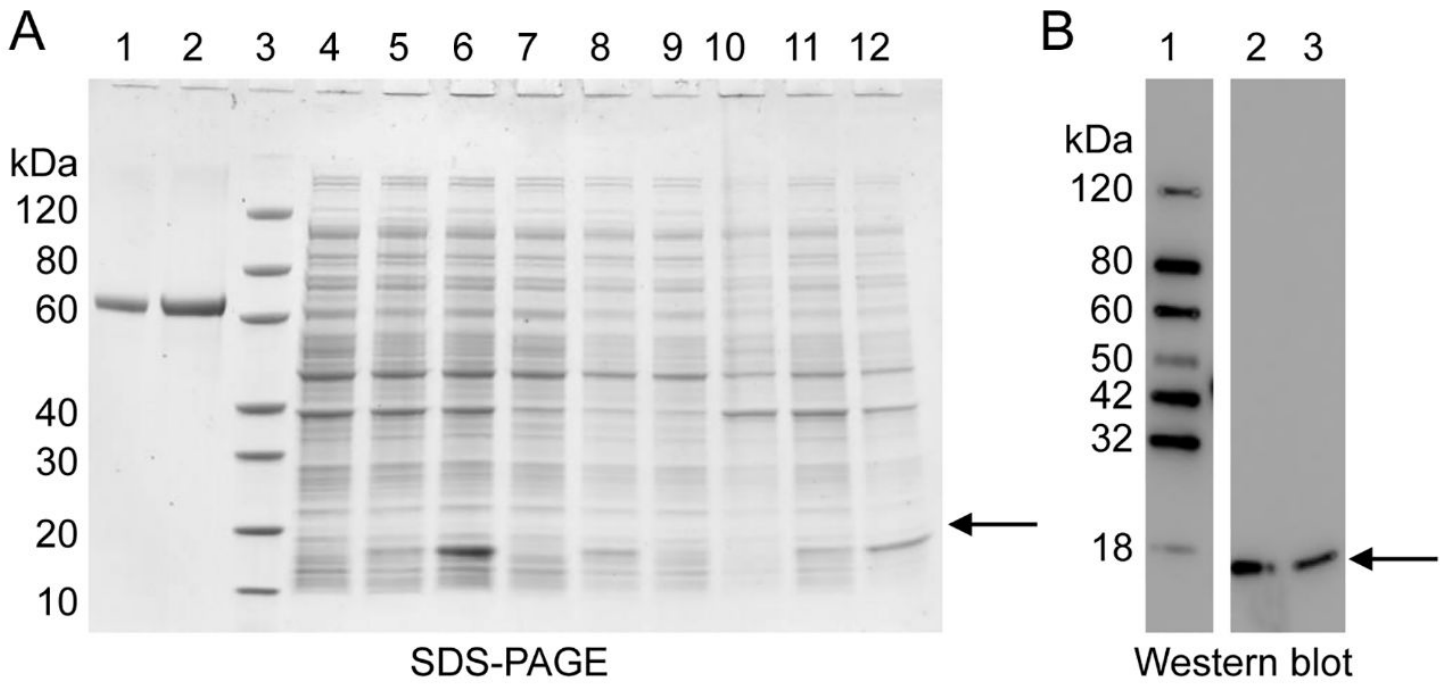

Supplemental Figure 1. Pilot expression and validation of MMBC1 under different conditions. (A) SDS-PAGE analysis of MMBC1 cloned in pET-30a(+) and expressed in BL21(DE3) strain. Lane 1: $1 \mu \mathrm{g}$ of bovine serum albumin [BSA]; Lane 2, $2 \mu \mathrm{g}$ of bovine serum albumin [BSA]; Lane 3, protein marker; Lane 4, cell lysate without induction; Lane 5, cell lysate with induction for $16 \mathrm{~h}$ at $15^{\circ} \mathrm{C}$; Lane 6 , cell lysate with induction for $4 \mathrm{~h}$ at $37^{\circ} \mathrm{C}$; Lane 7, supernatant of cell lysate without induction; Lane 8, supernatant of cell lysate with induction for $16 \mathrm{~h}$ at $15^{\circ} \mathrm{C}$; Lane 9 , supernatant of cell lysate with induction for $4 \mathrm{~h}$ at $37^{\circ} \mathrm{C}$; Lane 10 , debris of cell lysate without induction; Lane 11 , debris of cell lysate with induction for $16 \mathrm{~h}$ at $15{ }^{\circ} \mathrm{C}$; Lane 12 , debris of cell lysate with induction for $4 \mathrm{~h}$ at $37^{\circ} \mathrm{C}$. (B) Western blot analysis. Lane 1: Western blot marker; Lane 2: supernatant of cell lysate with induction for $16 \mathrm{~h}$ at $15{ }^{\circ} \mathrm{C}$; Lane 3: supernatant of cell lysate with induction for $4 \mathrm{~h}$ at $37{ }^{\circ} \mathrm{C}$. The primary antibody for western blot is the anti-His antibody (GenScript, Cat. No. A00186). The protein of interest (MMBC1) was indicated by the black arrow. 


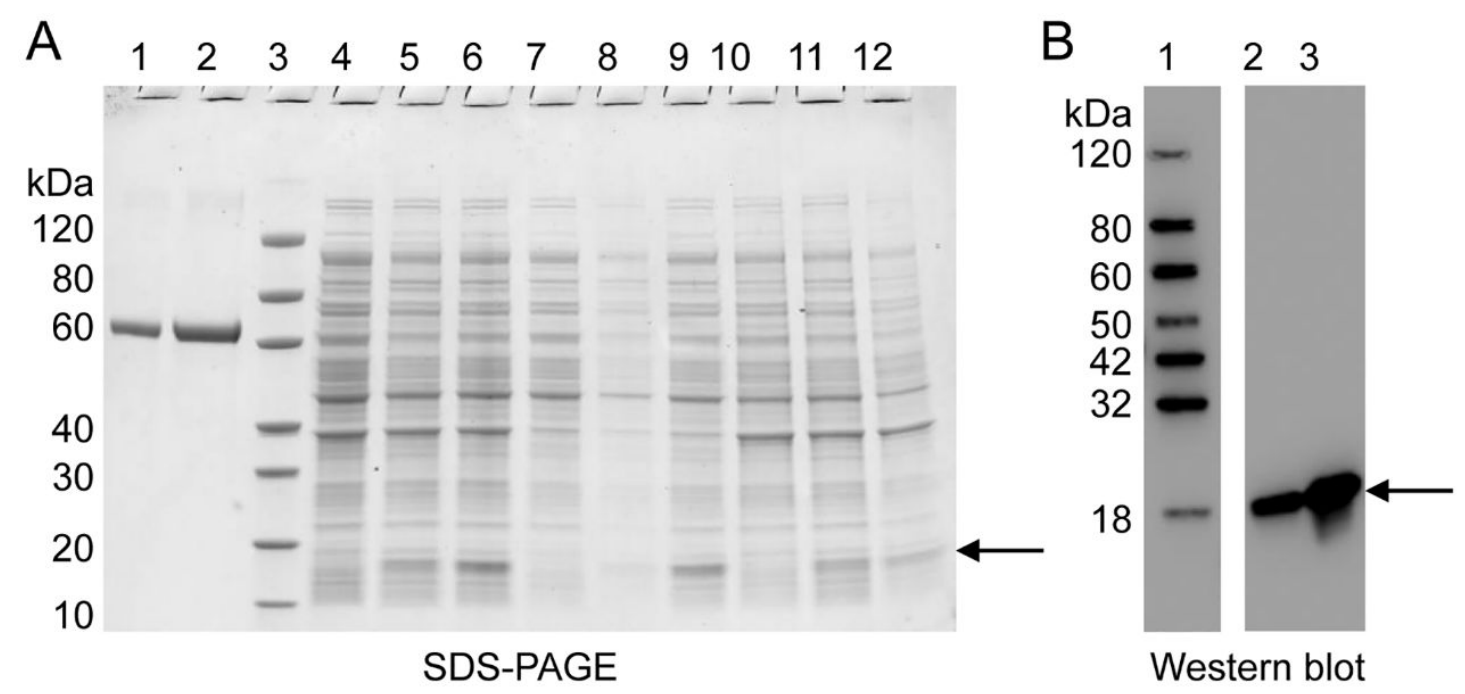

Supplemental Figure 2. Pilot expression and validation of MMBC2 under different conditions. (A) SDS-PAGE analysis of MMBC1 cloned in pET-30a(+) and expressed in BL21(DE3) strain. Lane 1: $1 \mu \mathrm{g}$ of bovine serum albumin [BSA]; Lane 2, $2 \mu \mathrm{g}$ of bovine serum albumin $[\mathrm{BSA}]$; Lane 3, protein marker; Lane 4, cell lysate without induction; Lane 5, cell lysate with induction for $16 \mathrm{~h}$ at $15^{\circ} \mathrm{C}$; Lane 6, cell lysate with induction for $4 \mathrm{~h}$ at $37^{\circ} \mathrm{C}$; Lane 7, supernatant of cell lysate without induction; Lane 8, supernatant of cell lysate with induction for $16 \mathrm{~h}$ at $15^{\circ} \mathrm{C}$; Lane 9 , supernatant of cell lysate with induction for $4 \mathrm{~h}$ at $37^{\circ} \mathrm{C}$; Lane 10 , debris of cell lysate without induction; Lane 11, debris of cell lysate with induction for $16 \mathrm{~h}$ at $15{ }^{\circ} \mathrm{C}$; Lane 12 , debris of cell lysate with induction for $4 \mathrm{~h}$ at $37^{\circ} \mathrm{C}$. (B) Western blot analysis. Lane 1: Western blot marker; Lane 2: supernatant of cell lysate with induction for $16 \mathrm{~h}$ at $15{ }^{\circ} \mathrm{C}$; Lane 3: supernatant of cell lysate with induction for $4 \mathrm{~h}$ at $37{ }^{\circ} \mathrm{C}$. The primary antibody for western blot is the anti-His antibody (GenScript, Cat. No. A00186). The protein of interest (MMBC2) was indicated by the black arrow. 

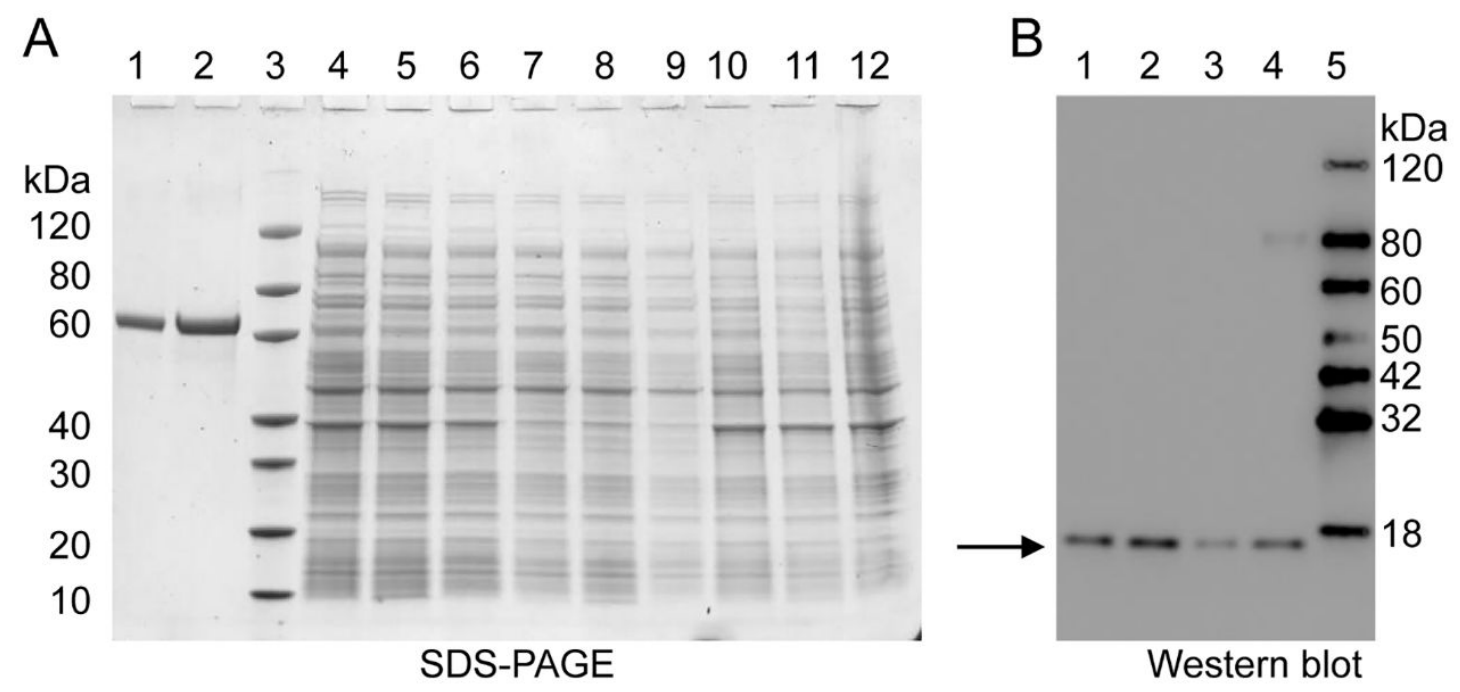

Supplemental Figure 3. Pilot expression and validation of MMBC3 under different conditions. (A) SDS-PAGE analysis of MMBC1 cloned in pET-30a(+) and expressed in BL21(DE3) strain. Lane 1: $1 \mu \mathrm{g}$ of bovine serum albumin [BSA]; Lane 2, $2 \mu \mathrm{g}$ of bovine serum albumin [BSA]; Lane 3, protein marker; Lane 4, cell lysate without induction; Lane 5, cell lysate with induction for $16 \mathrm{~h}$ at $15^{\circ} \mathrm{C}$; Lane 6 , cell lysate with induction for $4 \mathrm{~h}$ at $37^{\circ} \mathrm{C}$; Lane 7, supernatant of cell lysate without induction; Lane 8, supernatant of cell lysate with induction for $16 \mathrm{~h}$ at $15^{\circ} \mathrm{C}$; Lane 9 , supernatant of cell lysate with induction for $4 \mathrm{~h}$ at $37^{\circ} \mathrm{C}$; Lane 10 , debris of cell lysate without induction; Lane 11 , debris of cell lysate with induction for $16 \mathrm{~h}$ at $15{ }^{\circ} \mathrm{C}$; Lane 12 , debris of cell lysate with induction for $4 \mathrm{~h}$ at $37^{\circ} \mathrm{C}$. (B) Western blot analysis. Lane 1: supernatant of cell lysate with induction for $16 \mathrm{~h}$ at $15{ }^{\circ} \mathrm{C}$; Lane 2 : supernatant of cell lysate with induction for $4 \mathrm{~h}$ at $37^{\circ} \mathrm{C}$; Lane 3: debris of cell lysate with induction for $16 \mathrm{~h}$ at $15^{\circ} \mathrm{C}$; Lane 4: debris of cell lysate with induction for $4 \mathrm{~h}$ at $37^{\circ} \mathrm{C}$; Lane 5: Western blot marker. The primary antibody for western blot is the anti-His antibody (GenScript, Cat. No. A00186). The protein of interest (MMBC3) was indicated by the black arrow. 

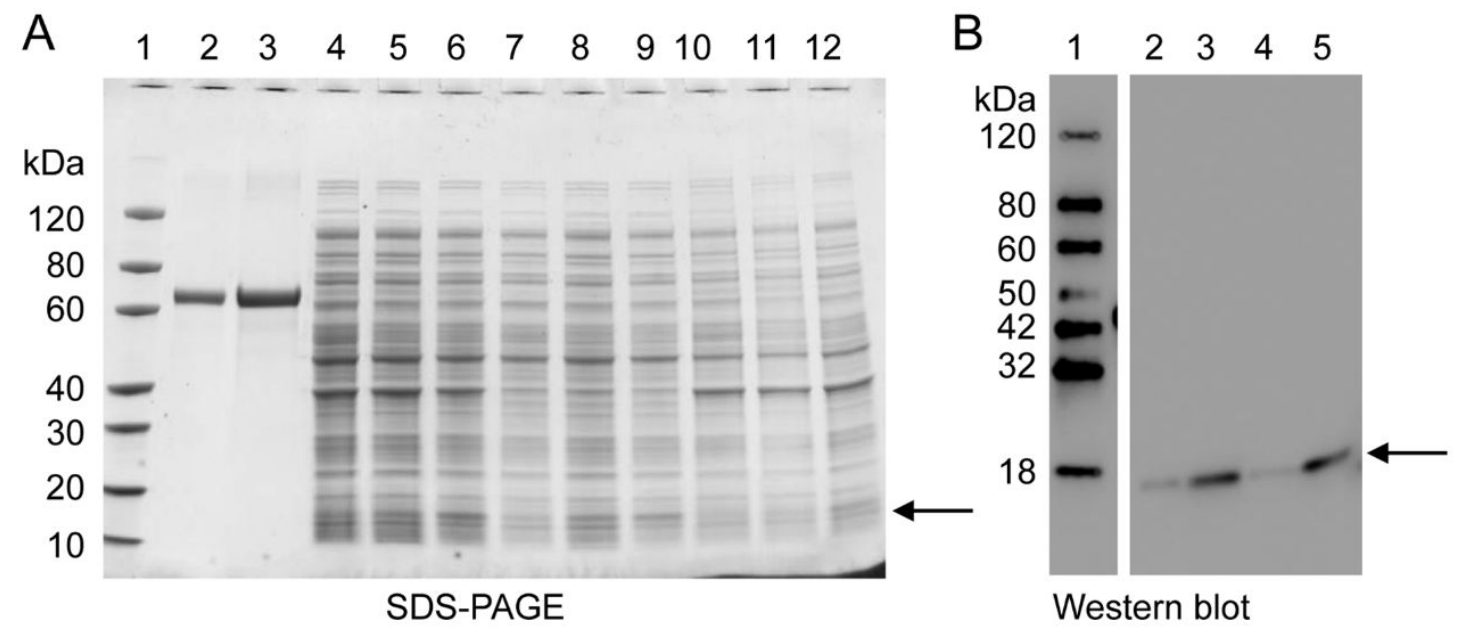

Supplemental Figure 4. Pilot expression and validation of MMBC4 under different conditions. (A) SDS-PAGE analysis of MMBC1 cloned in pET-30a $(+)$ and expressed in BL21(DE3) strain. Lane 1, protein marker; Lane 2: $1 \mu \mathrm{g}$ of bovine serum albumin [BSA]; Lane 3, $2 \mu \mathrm{g}$ of bovine serum albumin [BSA]; Lane 4, cell lysate without induction; Lane 5, cell lysate with induction for $16 \mathrm{~h}$ at $15^{\circ} \mathrm{C}$; Lane 6 , cell lysate with induction for $4 \mathrm{~h}$ at $37^{\circ} \mathrm{C}$; Lane 7, supernatant of cell lysate without induction; Lane 8, supernatant of cell lysate with induction for $16 \mathrm{~h}$ at $15^{\circ} \mathrm{C}$; Lane 9, supernatant of cell lysate with induction for $4 \mathrm{~h}$ at $37^{\circ} \mathrm{C}$; Lane 11 , debris of cell lysate with induction for $16 \mathrm{~h}$ at $15^{\circ} \mathrm{C}$; Lane 12 , debris of cell lysate with induction for $4 \mathrm{~h}$ at $37^{\circ} \mathrm{C}$. (B) Western blot analysis. Lane 1: Western blot marker; Lane 2: supernatant of cell lysate with induction for $16 \mathrm{~h}$ at $15{ }^{\circ} \mathrm{C}$; Lane 3 : supernatant of cell lysate with induction for $4 \mathrm{~h}$ at $\underline{37{ }^{\circ} \mathrm{C}}$; Lane 4: debris of cell lysate with induction for $16 \mathrm{~h}$ at $15^{\circ} \mathrm{C}$; Lane 5: debris of cell lysate with induction for $4 \mathrm{~h}$ at $37^{\circ} \mathrm{C}$; The primary antibody for western blot is the anti-His antibody (GenScript, Cat. No. A00186). The protein of interest (MMBC4) was indicated by the black arrow. 


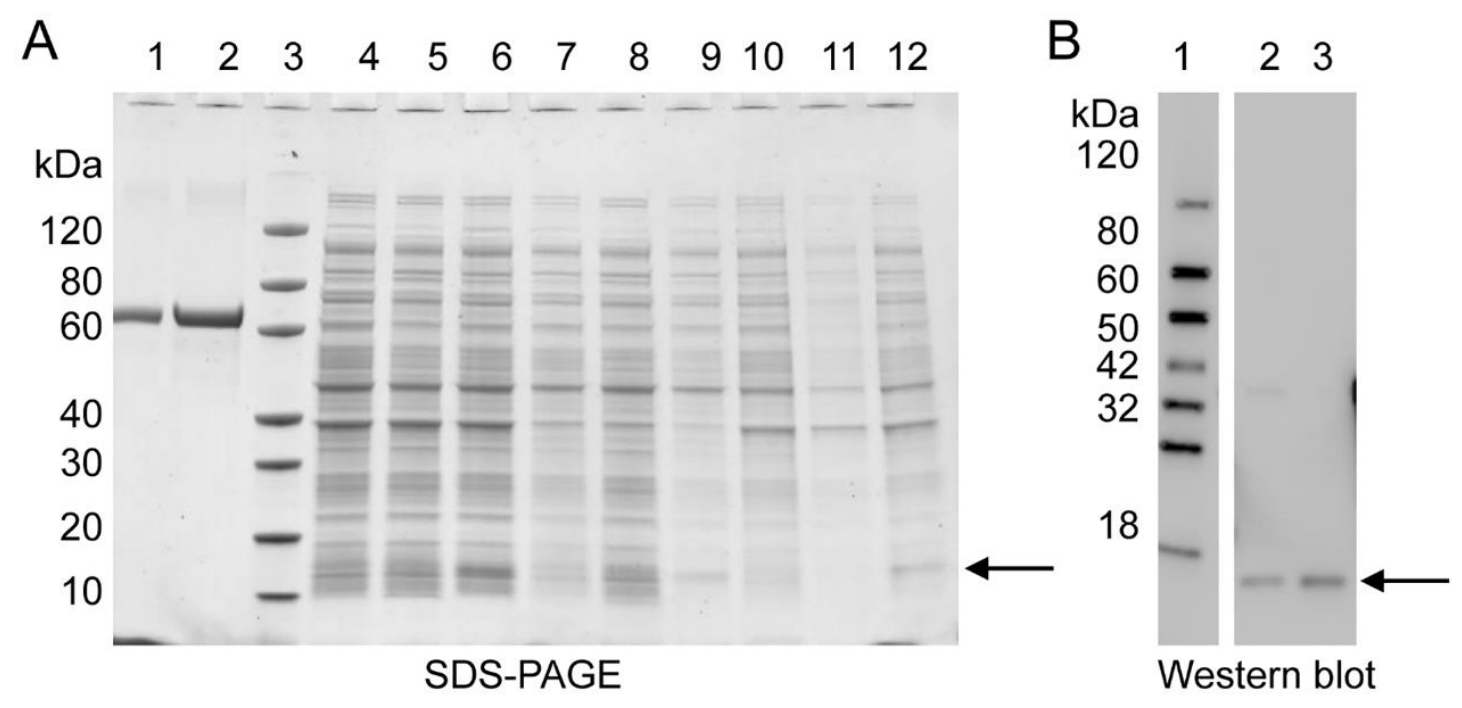

Supplemental Figure 5. Pilot expression and validation of MMBC5 under different conditions. (A) SDS-PAGE analysis of MMBC1 cloned in pET-30a(+) and expressed in BL21(DE3) strain. Lane 1: $1 \mu \mathrm{g}$ of bovine serum albumin [BSA]; Lane 2, $2 \mu \mathrm{g}$ of bovine serum albumin [BSA]; Lane 3, protein marker; Lane 4, cell lysate without induction; Lane 5, cell lysate with induction for $16 \mathrm{~h}$ at $15^{\circ} \mathrm{C}$; Lane 6 , cell lysate with induction for $4 \mathrm{~h}$ at $37^{\circ} \mathrm{C}$; Lane 7, supernatant of cell lysate without induction; Lane 8, supernatant of cell lysate with induction for $16 \mathrm{~h}$ at $15^{\circ} \mathrm{C}$; Lane 9, supernatant of cell lysate with induction for $4 \mathrm{~h}$ at $37^{\circ} \mathrm{C}$; Lane 10 , debris of cell lysate without induction; Lane 11, debris of cell lysate with induction for $16 \mathrm{~h}$ at $15^{\circ} \mathrm{C}$; Lane 12 , debris of cell lysate with induction for $4 \mathrm{~h}$ at $37^{\circ} \mathrm{C}$. (B) Western blot analysis. Lane 1: Western blot marker; Lane 2: supernatant of cell lysate with induction for $16 \mathrm{~h}$ at $15^{\circ} \mathrm{C}$; Lane 3: supernatant of cell lysate with induction for $4 \mathrm{~h}$ at $37{ }^{\circ} \mathrm{C}$. The primary antibody for western blot is the anti-His antibody (GenScript, Cat. No. A00186). The protein of interest (MMBC5) was indicated by the black arrow. 

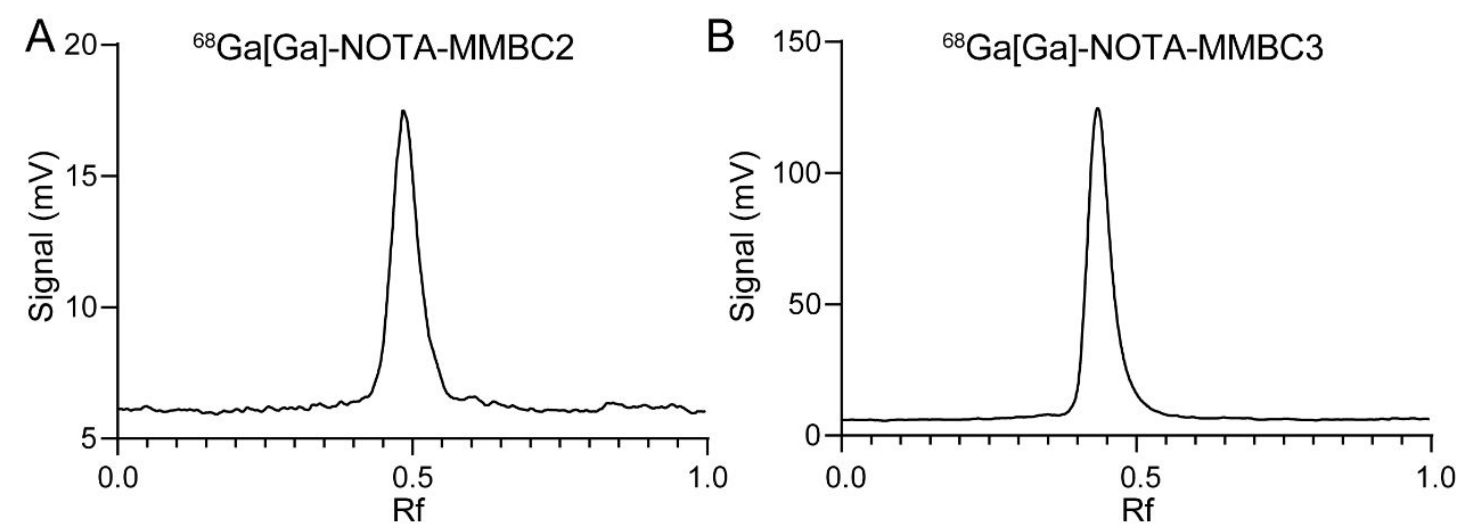

Supplemental Figure 6. Assessment of the radiochemical purities of $\left[{ }^{68} \mathrm{Ga}\right] \mathrm{Ga}-\mathrm{NOTA}$ MMBC2 (A) and $\left[{ }^{68} \mathrm{Ga}\right] \mathrm{Ga}-\mathrm{NOTA}-\mathrm{MMBC} 3$ (B) by radioactive instant thin-layer chromatography. 
a

PET

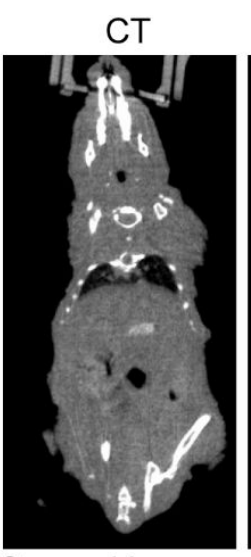

Coronal images

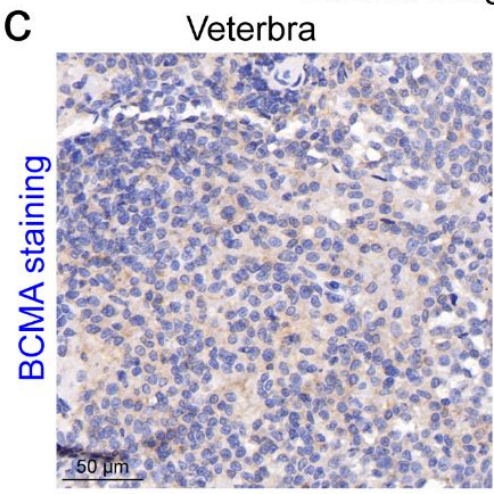

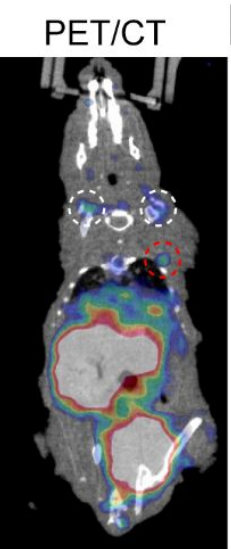

Skull base
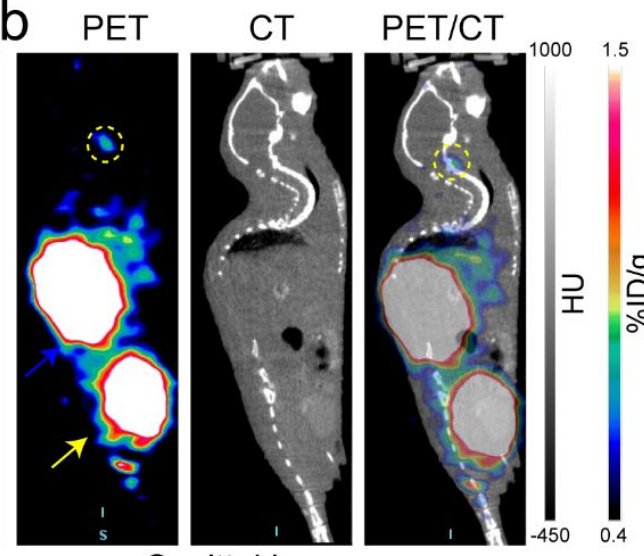

Sagittal images
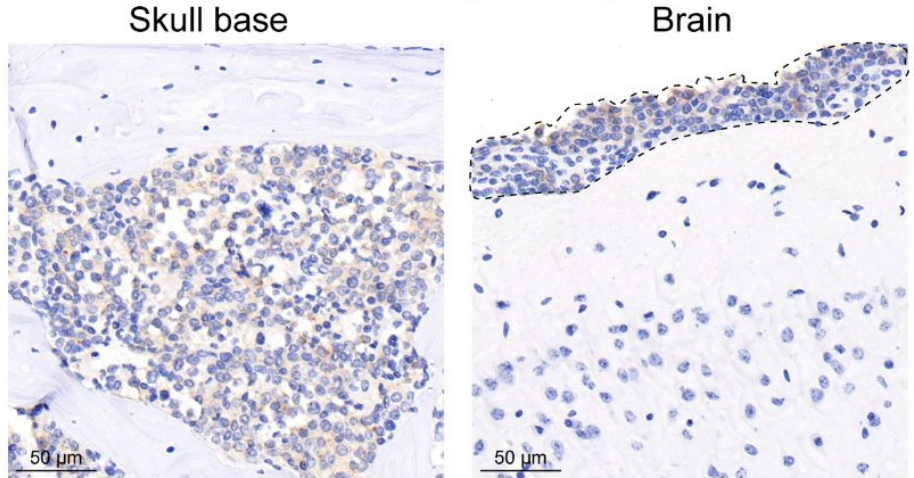

Supplemental Figure 7. $\left[{ }^{68} \mathrm{Ga}\right] \mathrm{Ga}-\mathrm{NOTA}-\mathrm{MMBC} 2$ immunoPET imaging in orthotopic multiple myeloma models. (A, B) ImmunoPET/CT images precisely delineated the involvement of humeri (white dashed circle), ribs (red dashed circles), and vertebra (yellow dashed circle) by multiple myeloma cells. The majority of the tracer was excreted from the urinary system into the bladder (yellow arrow). (C) Immunohistochemistry staining showed positive BCMA expression on the plasma cells, which infiltrated vertebrae (left), skull base (middle), and superior sagittal sinus (irregular black circle, right) but not the brain parenchyma. Blue arrow, kidney; yellow arrow, bladder. 


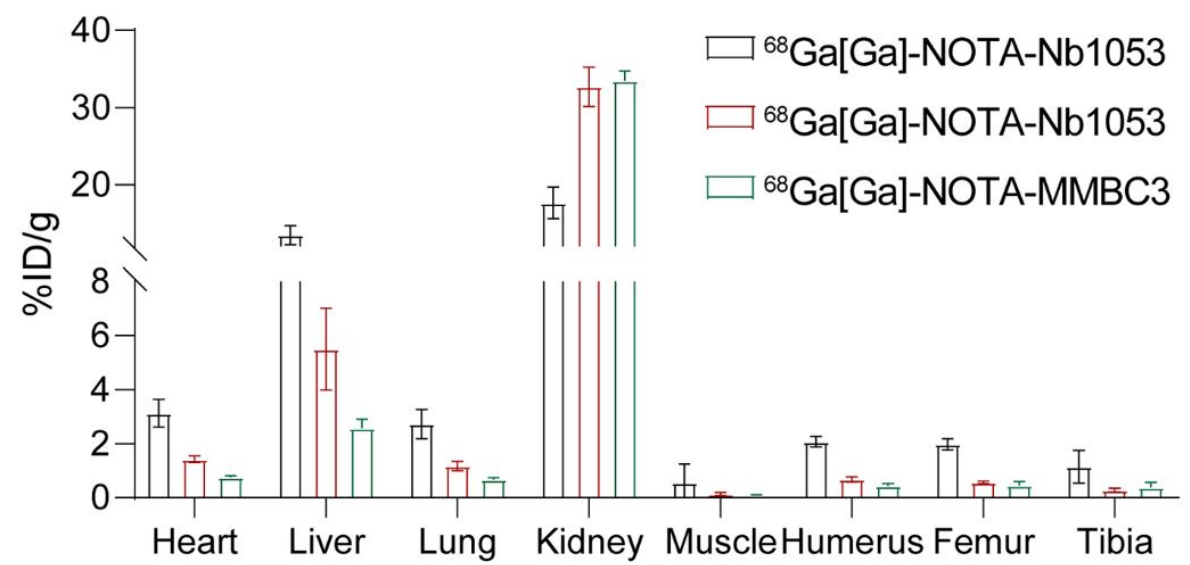

Supplemental Figure 8. Head-to-head comparison of the uptake of $\left[{ }^{68} \mathrm{Ga}\right] \mathrm{Ga}-\mathrm{NOTA}$ $\mathrm{Nb} 1053$ and $\left[{ }^{68} \mathrm{Ga}\right] \mathrm{Ga}-\mathrm{NOTA}-\mathrm{MMBC} 2$ in disseminated multiple myeloma models before and after daratumumab treatment. 